\title{
Comparison of Physicochemical Properties of Soils under Contrasting Land Use Systems in Southwestern Nigeria
}

\author{
Yoshinori WATANABE ${ }^{1}$, Hidehiko KIKUNO ${ }^{2}$, Robert ASIEDU ${ }^{3}$, \\ Tsugiyuki MASUNAGA ${ }^{4}$ and Toshiyuki WAKATSUKI ${ }^{1,4 *}$ \\ ${ }^{1}$ Faculty of Agriculture, Kinki University \\ (Nara, Nara 631-8505, Japan) \\ ${ }^{2}$ Miyako Subtropical Training and Research Farm, Tokyo University of Agriculture \\ (Miyakojima, Okinawa 906-0103, Japan) \\ ${ }^{3}$ International Institute of Tropical Agriculture \\ (Oyo Road, Ibadan, Nigeria)
}

\begin{abstract}
Soil physicochemical properties were determined for soils under cropland and forest at the headquarters of the International Institute of Tropical Agriculture in Ibadan, Southwestern Nigeria to examine the 30 -year effects of different land use on the fertility of five soil series toposequences underlain by a Basement Complex. The cropland had been under cultivation for 30 years, during which mainly maize and yams had been cultivated in rotation with application of chemical fertilizer and intermittent fallow, while the forest had secondary vegetation that had been regenerated during a 30 -year period under protection. The findings for cropland indicated an accumulation of available phosphorus and exchangeable potassium, soil compaction and slight depletion of topsoil organic carbon content; and the findings for forest indicated soil acidification and accumulation of exchangeable $\mathrm{Ca}$ at the surface soil horizon. These findings suggest the possibility of maintaining soil fertility with a long-term intensive and continuous crop farming system in kaolinitic Alfisol soil over the inland valley toposequences of tropical Africa.
\end{abstract}

Discipline: Soils, fertilizer and plant nutrition

Additional key words: continuous cultivation, forest restoration, maintain soil fertility, IITA

\section{Introduction}

Soil degradation and fertility depletion are the fundamental reasons for the decline of per-capita food production, hunger and malnutrition in Sub-Saharan Africa (Sanchez et al. 1997). It is estimated that the soils in this region have suffered an annual loss of $22 \mathrm{~kg} \mathrm{~N} \mathrm{ha}^{-1}, 2.5 \mathrm{~kg} \mathrm{Pha}^{-1}$, and $15 \mathrm{~kg} \mathrm{~K} \mathrm{ha}^{-1}$ as a result of low input farming systems for subsistence such as traditional slash-and-burn practices over the past 30 years (Smaling et al. 1997). This annual loss is equivalent to US $\$ 4$ billion in fertilizer (Sanchez 2002). The longer cultivation period and shortened fallow duration under ever-increasing demographic pressure have been threatening the productivity and sustainability of the traditional farming systems. Viable alternatives to these systems are required in the transition from traditional shift- ing cultivation to semi-permanent systems through the use of fertilizers.

Soil fertility management is key to the sustainability of prolonged, semi-permanent farming systems that enable cropping intensification. Sanchez et al. $(1982,1983)$ documented an improvement in $\mathrm{pH}$, exchangeable $\mathrm{Ca}$ and available $\mathrm{P}$ of soil in a highly weathered red soil (Typic Paleudult) of the Amazon Basin during an 8-year period of consecutive cultivation after forest clearing as a result of the application of chemical fertilizer (annual rates: 80$\left.100 \mathrm{~kg} \mathrm{~N} \mathrm{ha}^{-1}, 25 \mathrm{~kg} \mathrm{Pha}^{-1}, 80-100 \mathrm{~kg} \mathrm{~K} \mathrm{ha}^{-1}\right)$. In contrast, Juo and Lal (1977) and Juo et al. (1995a, 1995b, 1996) found a declining trend in the same soil properties and crop productivity in a kaolinitic Alfisol (Oxic Kandiustalf) of tropical Nigeria during a 10- to 18 -year period of consecutive cultivation despite continuous application of the

\section{Present address:}

${ }^{4}$ Faculty of Life and Environmental Science, Shimane University (Matsue, Shimane 690-8504, Japan)

*Corresponding author: e-mail wakatuki@life.shimane-u.ac.jp

Received 10 February 2014; accepted 6 April 2015. 
recommended amount of chemical fertilizer (annual rate: $150 \mathrm{~kg} \mathrm{~N} \mathrm{ha}^{-1}$, 26-30 $\mathrm{kg} \mathrm{P} \mathrm{ha}^{-1}, 25-40 \mathrm{~kg} \mathrm{~K} \mathrm{ha}^{-1}$ ). These contradictory reports suggest the need for further research to examine long-term trends of soil fertility in various tropical soils under semi-permanent cultivation through the use of chemical fertilizer.

Furthermore, deforestation and forest degradation are major issues in tropical regions in relation to environmental deterioration, loss of biodiversity, greenhouse gas emissions, and ecosystem service reduction (Chazdon 2008, Lamb et al. 2005). Forest clearing and land reclamation for agriculture are major causes of deforestation and forest degradation (Detwiler 1986, Don et al. 2011). In contrast, afforestation and reforestation are reliable options for restoring degraded and abandoned lands. Natural bush regrowth is currently considered the most efficient type of fallow for nutrient recycling and biomass accumulation because it consists of many plant species with different types of root systems (Ewel 1986, Jaiyebo \& Moore 1964). However, changes in the characteristics of soil fertility during forest regeneration as long-term natural fallow have not been fully explored in tropical Africa.

It was hypothesized that soil fertility in the continued cultivation of lands with chemical fertilizer would be lower than that of long-term fallow lands in highly weathered tropical soil. The aim of this study was to assess changes in soil fertility under contrasting land-use systems in Sub-Saharan Africa. The physicochemical properties of soil under cropland and secondary forest were examined over five soil series along toposequences overlying Basement Complex rocks in Southwestern Nigeria. Here, these croplands have been cultivated with fertilizer and intermittent short fallow for 30 years, while the secondary forests, which feature highly weathered tropical soil, have not been cultivated for the same period of time.

\section{Materials and Methods}

\section{Study site}

The study site is located at the headquarters of the International Institute of Tropical Agriculture (IITA) $\left(7^{\circ} 30^{\prime} \mathrm{N}, 3^{\circ} 54^{\prime} \mathrm{E}\right)$ in Ibadan, Southwestern Nigeria. This site is situated in a transitional zone from forest to savanna, including a derived savanna area with a sub-humid tropical climate. Rainfall distribution is bimodal. The rainy season normally begins in April and ends in November with a short break (minor dry season) in August. The major dry season lasts from December to March. Mean annual precipitation and monthly temperature were in the range of $790-1930 \mathrm{~mm}$ and $22.5-30.0^{\circ} \mathrm{C}$ and averaged $1310 \mathrm{~mm}$ and $26.5^{\circ} \mathrm{C}$, respectively, from 1981 to 2010 , according to the IITA weather record.

The headquarters campus has a total area of 1000 ha and includes nine lakes, the largest of which ( $70 \mathrm{ha}$ ) lies north to south in the middle of the campus dividing the area into two major parts; namely, the forest reserve area $(350 \mathrm{ha})$ in the west and the experimental field area (230 ha) in the east. The landscape is dominated by a gently undulating peneplain (slope gradients $<15 \%$ ) that forms small headwater swamps (called inland valleys) between the ridges. The soils at the study site are underlain by metamorphic rocks of the Pre-Cambrian Basement Complex consisting of banded gneiss, quartzites, quartz schists, and granitic gneisses (Moorman et al. 1975), and generally have a sandy loam topsoil and a gravelly and clayey subsoil, being classified into Alfisols. Soil mineralogy is dominated by kaolinite and quartz in the clay and fine-sand fraction, respectively (Abe et al. 2006, 2007a, Moormann et al. 1975). These characteristics represent low activity clay soil in this region (Kang \& Spain 1986).

\section{Land use history and farm management}

The study site had been occupied by a local population engaged in the traditional slash-and-burn farming of maize (Zea mays), cassava (Manihot esculenta), and cocoyam (Colocasia esculenta) as well as oil palms (Elaeis spp.). IITA assumed control of the site in 1967.

IITA has recorded land use and management practices in its experimental farm (cropland) since 1998. No farm record is available before this. The farm record indicates that the croplands have been cultivated predominantly with maize, cassava and yam (Dioscorea spp.), and left intermittently for natural or improved fallow with Mucuna spp. Nevertheless, no official record of the rate of fertilization was available when the present study commenced. However, a review of the previous reports on the field experiments conducted at the IITA headquarters campus over the past 30 years revealed annual rates of chemical fertilizer application for maize production at: $50-120 \mathrm{~kg} \mathrm{~N} \mathrm{ha}^{-1}, 30-$ $60 \mathrm{~kg} \mathrm{P}_{2} \mathrm{O}_{5} \mathrm{ha}^{-1}$, and 30-60 $\mathrm{kg} \mathrm{K}_{2} \mathrm{O} \mathrm{ha}^{-1}$ (Egesi et al. 2007, Ekleme et al. 2004, Muhr et al. 2002). No fertilizer was used for yam and cassava production in most cases. In addition, an informal interview with the farm manager and field officers indicated that identical cropping systems and management practices, including the fertilizer application method, have been employed since IITA was established in 1967.

The secondary tropical semi-deciduous forest has been regenerating in the forest reserve for more than 30 years due to protection from anthropogenic disruption such as undergrowth burning during the dry season. This means that the forest reserve can be considered a long-term natural fallow site. The secondary forest in the IITA forest reserve basically exhibits a four-layered structure composed of a discontinuous emergent canopy of Milicia excelsa, Celtis zenkeri, Terminalia superb, and Antiaris africana, a tree 
canopy of Blighia sapida, young Ceiba pentandra, Entandrophragma angolense, and Ricinodendron heudelotii as the more frequent woody plants, a shrub layer of Newbouldia laevis and Baphia nitida and a herb layer of the family Orchdaceae and some Poaceae and Chromolaena spp. in the more open areas (Hall \& Okali 1979). The forest vegetation around the Ibadan region has a scarcity value because of extensive agricultural operations and rapid urbanization.

\section{Field survey and soil sampling}

Field surveys and soil sampling were conducted in August-September 2006. Referring to a soil map provided by IITA and soil survey information documented by Moormann et al. (1975) and Smyth and Montgomery (1962), survey locations were selected over five soil toposequences on different series: Ekiti (Dystroxerepts), Iwo (Paleustalfs), Egbeda (Paleustalfs), Iregun (Haplustalfs), and Ikire series (Epiaquents) (Fig. 1; Fig. 2; Soil Survey Staff 2006) because soil properties often vary considerably over the toposequence (e.g., Abe et al. 2007b, 2009b, 2009c). Both cropland and secondary forest were further selected within each soil series, except for the Ekiti series, which was only covered by secondary forest. For description of soil morphology and sample collection, a soil pit (up to $1.5 \mathrm{~m}$ deep unless lithic contact was made at a shallower depth) was freshly prepared at each survey location. Soil morphology within each soil profile was observed by Soil Survey Staff
(1993).

The soil profiles in the inland valley investigated in this study area were previously described by Moorman et al. (1975) and Smyth and Montgomery (1962) (Fig. 2). The Ekiti series is located on the upper slope of the ridge (slope $=5 \%$ ), has an irregular boundary, lithic contact at a shallow depth, and originates from banded and weathered gneiss. The Egbeda series occurs on a 1-3\% convex slope on ridges and originates from fine-grained biotite gneiss and schist. The Iwo series also appears on a 1-3\% convex slope on ridges and derives from sedentary material from coarse grained granite and banded gneiss overlain by colluvium. This series is further divided into standard, sandy and concretionary phases. The sandy and concretionary phases represent more sandy texture throughout the soil profile and the presence of more $\mathrm{Fe}$ or Mn concretions than the standard phase (hereafter shown as 'the Iwo series'). The Iregun series lies on a fairly flat slope $(<2 \%)$ at the head of the lower toposequence position in the inland valley, and formed on old colluvium of weathered Basement Complex rocks. This series has a relatively thick A horizon $(22-32 \mathrm{~cm}$ in depth) and contains no gravells to at least $50 \mathrm{~cm}$. The Ikire series occurs in a swamp area at the inland valley bottom, originates from sandy alluvium and colluvium over older, sedentary, clayey substrate, and has redoximorphic features under poorly drained conditions with a relatively high ground water table.

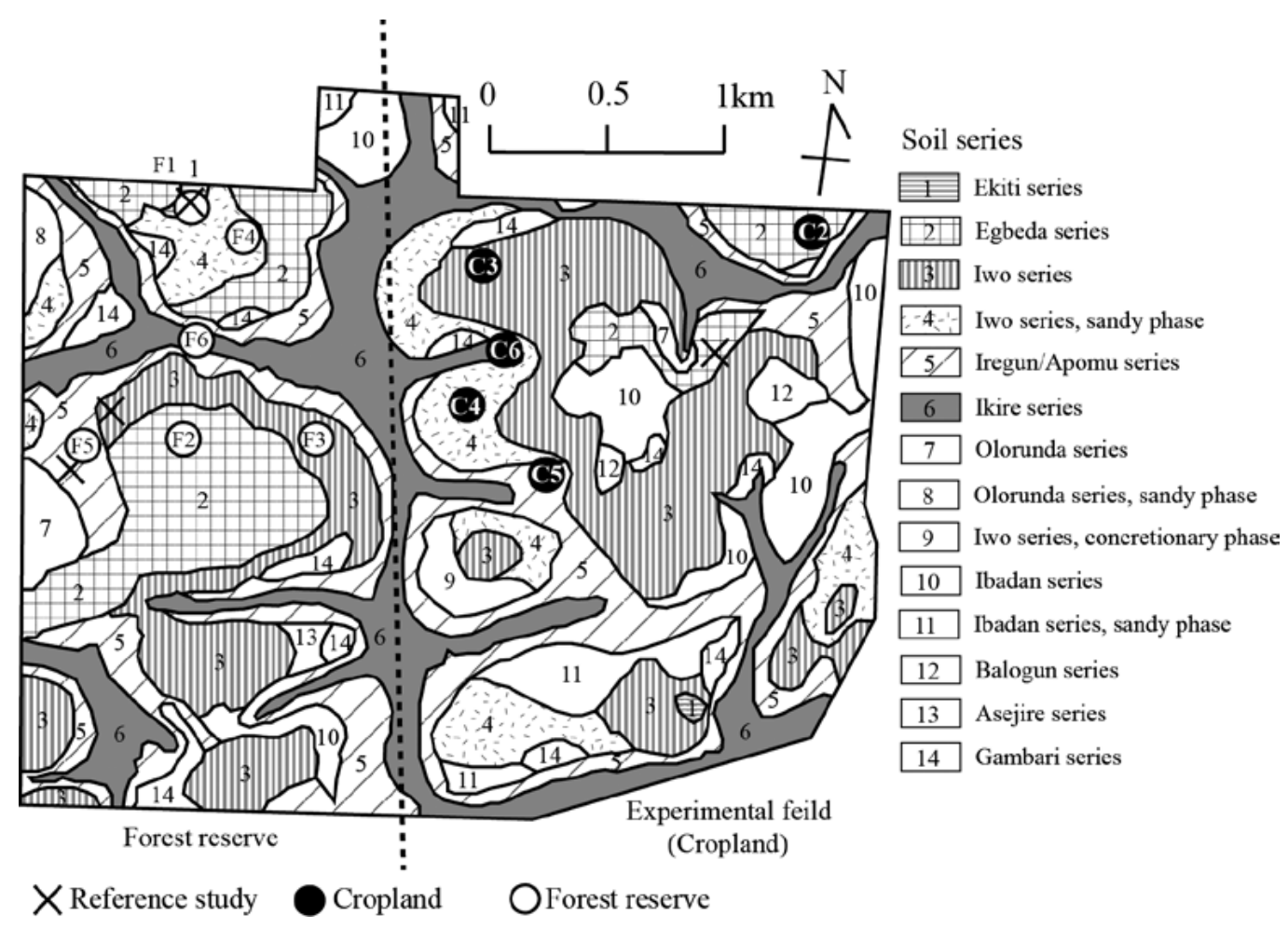

Fig. 1. Soil sampling locations at the study site. Soil map provided by IITA. Adapted from Moormann et al (1975). 


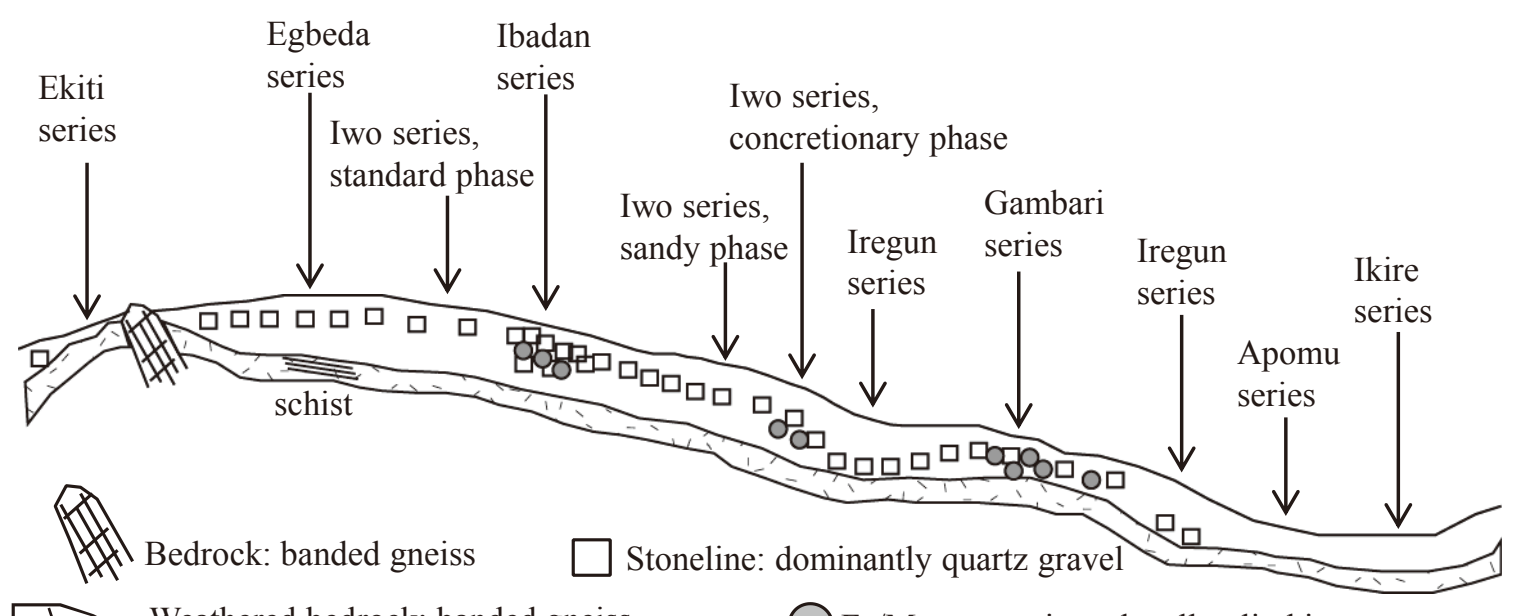

Weathered bedrock: banded gneiss,
granite gneiss, some schist

$\mathrm{Fe} / \mathrm{Mn}$ concretions, locally plinthite

Fig. 2. Schematic cross section of the inland valley toposequences at the study site. Adapted from Moormann et al (1975).

After description of the soil profile, duplicate soil samples were collected from each horizon using a $100 \mathrm{~cm}^{3}$ stainless steel cylinder. Soil moisture content was obtained after a $5 \mathrm{~g}$ sample was oven dried at $105^{\circ} \mathrm{C}$ for $24 \mathrm{~h}$, and bulk density was determined by correction of soil moisture content. The remaining samples were air dried and sieved to $2 \mathrm{~mm}$ for laboratory analysis.

\section{Laboratory analysis}

The glass electrode method was used to determine soil $\mathrm{pH}$ in $1 \mathrm{~mol} \mathrm{~L}^{-1}$ potassium chloride $(\mathrm{KCl})$ and in water (soil: solution $=1: 1$, and are hereafter shown as $\mathrm{pH}_{\mathrm{KCl}}$ and $\mathrm{pH}_{\text {water, }}$ respectively. Organic carbon (C) content was measured by the Walkley-Black (dichromate-oxidation) procedure. Total nitrogen $(\mathrm{N})$ content was measured using an elemental analyzer (SUMIGRAPH NC-22A; Sumika Chemical Analysis Service Ltd., Osaka, Japan). Exchangeable calcium (Ca), magnesium $(\mathrm{Mg})$, potassium $(\mathrm{K})$, and sodium $(\mathrm{Na})$ were extracted from the soil with $1 \mathrm{~mol} \mathrm{~L}^{-1}$ neutral ammonium acetate, and were subsequently determined using an atomic adsorption spectrophotometer (Z-2300; Hitachi Tech, Co., Tokyo, Japan). Exchange acidity was determined by the sodium hydroxide titration method after extraction with $1 \mathrm{~mol} \mathrm{~L}^{-1} \mathrm{KCl}$. Available phosphorus (P) was extracted by the Bray-1 method followed by colorimetric measurement using an ultraviolet/visible spectrophotometer (V-630; JASCO Co., Tokyo, Japan) after color development with molybdate under the presence of ascorbic acid. All analyses were conducted according to the IITA standard soil analysis manual (IITA 1979), except for the dry combustion measurement of total N. Effective cation exchange capacity (ECEC) was calculated by summation of exchangeable bases and exchange acidity, whereas base saturation percentage was expressed as a proportion of the sum of exchangeable bases to ECEC.

\section{Data processing and analysis}

The physicochemical properties of three different soil depths were arranged in order to investigate the effects of land-use change. Different soil depths were Surface horizon (top soil horizon), Upper horizon (average of 0-50 cm horizons) and Lower horizon (average of below $50 \mathrm{~cm}$ horizons). Scheffe's test was used to compare the physicochemical properties of soil among cropland, forest and reference survey data (Moorman et al. 1975) under difference land use conditionss. Soil data originated from cropland and forest were analyzed to calculate Pearson's correlation coefficients among soil fertility parameters. All statistical analyses were performed on SPSS ver. 15.0.

\section{Results and Discussion}

\section{Soil profile description}

Table 1 shows morphological features of the examined pedons over six soil series under the contrasting land use systems in IITA. Soil horizon characteristics showed several similarities at each soil series between the present study and 1975 survey (Moorman et al. 1975). In general, the soils had sandy texture especially in the surface horizons, and a clayey texture in the lower horizons. Soil texture generally become finer with increasing soil depth along with the occurrence of clay cutan in the ped surface of the subsoil horizons. The Ekiti series had a shallow soil depth with a sandy texture. The Iwo sandy series showed a sandy texture 
Table 1. Morphological characteristics of soil pedons at IITA

\begin{tabular}{|c|c|c|c|c|c|c|c|c|}
\hline $\begin{array}{c}\text { Soil } \\
\text { series }\end{array}$ & $\begin{array}{c}\text { Pedon } \\
\text { ID }^{\dagger}\end{array}$ & Horizon & $\begin{array}{l}\text { Depth } \\
(\mathrm{cm})\end{array}$ & $\begin{array}{c}\text { Field } \\
\text { texture }\end{array}$ & $\begin{array}{c}\text { Coarse } \\
\text { fragment }\end{array}$ & Structure & $\begin{array}{l}\text { Matrix and Mottling Color } \\
\text { Matrix(Mottling) }\end{array}$ & $\begin{array}{l}\text { Plinthite and } \\
\text { concretion }^{t+\dagger}\end{array}$ \\
\hline \multirow[t]{5}{*}{ Ekiti } & F1 & A & $0-5$ & $\mathrm{~L}$ & None & ST, FI to ME, GR and CR & $5 \mathrm{YR} 2 / 2$ & $\mathrm{~N}$ \\
\hline & & $\mathrm{AB}$ & $5-30$ & SL & None & $\mathrm{MO}, \mathrm{ME}, \mathrm{SB}$ and GR & $5 Y R 3 / 4$ & $\mathrm{~N}$ \\
\hline & & $\mathrm{B}$ & $30-47$ & SCL & $\mathrm{F}, \mathrm{PE}, \mathrm{QU}$ & MO, ME, GR & $5 Y R 4 / 8$ & $\mathrm{~N}$ \\
\hline & & $\mathrm{C}$ & $47-55 / 80$ & SCL & $\mathrm{F}, \mathrm{GR}, \mathrm{GN}$ & MO, FI, GR & 5YR3/4 (5YR6/8) & $\mathrm{N}$ \\
\hline & & $\mathrm{R}$ & $55 / 80-$ & & Fresh gneiss & & & \\
\hline \multirow[t]{9}{*}{ Egbeda } & $\mathrm{C} 2$ & Ap & $0-12$ & SL & $\mathrm{C}, \mathrm{GR}, \mathrm{QU}$ & $\mathrm{MO}, \mathrm{FI}, \mathrm{AB}$ & $5 \mathrm{YR} 3 / 3$ & $\mathrm{~N}$ \\
\hline & & Bt1 & $12-30$ & SCL & $\mathrm{C}$ to $\mathrm{M}, \mathrm{PE}, \mathrm{QU}$ & WE, FI to ME, COL & $5 \mathrm{YR} 4 / 6$ & $\mathrm{~N}$ \\
\hline & & Bt2 & $30-67$ & $\mathrm{SC}$ & $\mathrm{F}$ to $\mathrm{C}, \mathrm{PE}$ to $\mathrm{CO}, \mathrm{QU}$ & WE, FI to ME, COL & $5 Y R 5 / 8$ & $\mathrm{~N}$ \\
\hline & & $\mathrm{C}$ & $67-90$ & $\mathrm{C}$ & $\mathrm{C}, \mathrm{PE}$ to $\mathrm{CO}, \mathrm{QU}$ & $\mathrm{WE}, \mathrm{ME}$ to $\mathrm{CO}, \mathrm{COL}$ & 2.5YR5/8 (10YR7/6) & SP \\
\hline & & $\mathrm{Cv}$ & $90-150+$ & $\mathrm{C}$ & F, GR to PE, QU & MA & 10YR8/3, 10YR7/6 (2.5YR4/8) & SP \\
\hline & $\mathrm{F} 2$ & A & $0-12$ & SL & $\mathrm{F}, \mathrm{GR}, \mathrm{QU}$ & MO, ME, GR & $2.5 \mathrm{YR} 3 / 2$ & $\mathrm{~N}$ \\
\hline & & Bt1 & $12-35$ & SCL & M, GR to PE, QU & WE, FI, SB & $2.5 \mathrm{YR} 3 / 6$ & $\mathrm{~N}$ \\
\hline & & Bt2 & $35-70$ & CL & M, GR to PE, QU & WE, FI, SB & $2.5 \mathrm{YR} 5 / 6$ & $\mathrm{~N}$ \\
\hline & & $\mathrm{Cv}$ & $70-150+$ & CL & None & MA & 5YR6/8 (2.5YR5/8) & $\mathrm{HP}, \mathrm{FeC}$ \\
\hline \multirow[t]{10}{*}{ Iwo } & $\mathrm{C} 3$ & Ap & $0-15$ & LS & F, GR, QU & MO to ST, ME, GR & $5 Y R 4 / 4$ & $\mathrm{~N}$ \\
\hline & & A & $15-32$ & LS & $\mathrm{A}, \mathrm{PE}, \mathrm{QU}$ & $\mathrm{MO}, \mathrm{ME}, \mathrm{SB}$ & $5 Y R 3 / 6$ & $\mathrm{~N}$ \\
\hline & & $\mathrm{B}$ & $32-50$ & $\mathrm{SC}$ & $\mathrm{M}, \mathrm{PE}$ to $\mathrm{CO}, \mathrm{QU}$ & $\mathrm{MO}, \mathrm{FI}$ to $\mathrm{ME}, \mathrm{AB}$ & $2.5 \mathrm{YR} 5 / 6$ & $\mathrm{~N}$ \\
\hline & & $\mathrm{Bt}$ & $50-80$ & $\mathrm{LC}$ & $\mathrm{F}$ to $\mathrm{C}, \mathrm{GR}$ to $\mathrm{CO}, \mathrm{QU}$ & WE, ME, AB & $2.5 \mathrm{YR} 5 / 8$ & $\mathrm{~N}$ \\
\hline & & $\mathrm{C}$ & $80-150+$ & $\mathrm{C}$ & $\mathrm{F}, \mathrm{GR}$ to $\mathrm{CO}, \mathrm{QU}$ & MA & 5YR4/6 (5YR6/8) & SP \\
\hline & F3 & $\mathrm{A} 1$ & $0-10$ & $\mathrm{~L}$ & None & $\mathrm{MO}, \mathrm{FI}, \mathrm{GR}$ & $7.5 \mathrm{YR} 4 / 3$ & $\mathrm{~N}$ \\
\hline & & A2 & $10-17$ & $\mathrm{LC}$ & F, GR, QU & MO, FI, SB & 7.YR5/4 & $\mathrm{N}$ \\
\hline & & Bt1 & $17-45$ & $\mathrm{C}$ & $\mathrm{C}, \mathrm{PE}, \mathrm{QU}$ & WE to $\mathrm{MO}, \mathrm{ME}, \mathrm{AB}$ & $5 Y R 4 / 6$ & $\mathrm{~N}$ \\
\hline & & $\mathrm{Bt} 2$ & $45-76$ & $\mathrm{C}$ & None & $\mathrm{WE}, \mathrm{ME}$ to $\mathrm{CO}, \mathrm{AB}$ & 5 YR6/8 & $\mathrm{N}$ \\
\hline & & $\mathrm{C}$ & $76-150+$ & $\mathrm{L}$ & None & MA & 5YR6/8 (5YR4/4, 2.5YR4/8) & SP \\
\hline \multirow[t]{10}{*}{ Iwo, Sandy } & $\mathrm{C} 4$ & Ap & $0-13$ & LS & $\mathrm{F}, \mathrm{GR}, \mathrm{QU}$ & $\mathrm{MO}, \mathrm{FI}$ to $\mathrm{ME}, \mathrm{SB}$ and GR & $5 \mathrm{YR} 4 / 3$ & $\mathrm{~N}$ \\
\hline & & A & $13-40$ & LS & F, GR, QU & WE to MO, FI to ME, COL and SB & $5 Y R 3 / 4$ & $\mathrm{~N}$ \\
\hline & & $\mathrm{AB}$ & $40-100$ & LS & None & WE, FI to ME, AB & $5 \mathrm{YR} 4 / 4$ & $\mathrm{~N}$ \\
\hline & & B & $100-125$ & $\mathrm{SC}$ & $\mathrm{C}, \mathrm{GR}$ to $\mathrm{PE}, \mathrm{WR}$ & MA & $5 Y R 3 / 6$ & $\mathrm{~N}$ \\
\hline & & $\mathrm{C}$ & $125-150+$ & $\mathrm{SC}$ & $\mathrm{C}, \mathrm{GR}, \mathrm{WR}$ and $\mathrm{QU}$ & MA & $5 \mathrm{YR} 4 / 6$ & $\mathrm{SP}, \mathrm{FeC}, \mathrm{MnC}$ \\
\hline & $\mathrm{F} 4$ & $\mathrm{~A} 1$ & $0-13$ & SL & None & $\mathrm{MO}, \mathrm{FI}$ to $\mathrm{ME}, \mathrm{GR}$ & $5 \mathrm{YR} 3 / 3$ & $\mathrm{~N}$ \\
\hline & & A2 & $13-30$ & SL & $\mathrm{M}, \mathrm{GR}$ to $\mathrm{PE}, \mathrm{QU}$ & WE to MO, ME, GR & $5 \mathrm{YR} 3 / 6$ & $\mathrm{~N}$ \\
\hline & & Bt1 & $30-60$ & $\mathrm{C}$ & $\mathrm{F}, \mathrm{GR}, \mathrm{QU}$ & $\mathrm{MO}, \mathrm{FI}$ to $\mathrm{ME}, \mathrm{AB}$ and $\mathrm{SB}$ & $5 \mathrm{YR} 5 / 8$ & $\mathrm{~N}$ \\
\hline & & $\mathrm{Bt} 2$ & $60-100$ & $\mathrm{C}$ & None & WE to $\mathrm{MO}, \mathrm{ME}, \mathrm{AB}$ & $2.5 \mathrm{YR} 5 / 8$ & $\mathrm{~N}$ \\
\hline & & $\mathrm{Cv}$ & $100-150+$ & $\mathrm{C}$ & $\mathrm{C}, \mathrm{PE}$ to $\mathrm{CO}, \mathrm{QU}$ & MA & 10YR4/6 (5YR6/8) & SP \\
\hline \multirow[t]{10}{*}{ Iregun } & $\mathrm{C} 5$ & Ap & $0-10$ & LS & $\mathrm{F}, \mathrm{GR}, \mathrm{QU}$ & MO, ME, GR & $7.5 \mathrm{YR} 4 / 4$ & $\mathrm{~N}$ \\
\hline & & $\mathrm{A} 1$ & $10-20$ & LS & $\mathrm{F}, \mathrm{GR}, \mathrm{QU}$ & $\mathrm{MO}, \mathrm{FI}$ to $\mathrm{ME}, \mathrm{SB}$ and GR & $7.5 \mathrm{YR} 4 / 6$ & $\mathrm{~N}$ \\
\hline & & $\mathrm{A} 2$ & $20-32$ & LS & None & WE to MO, FI to ME, SB and GR & $5 Y R 4 / 6$ & $\mathrm{FeC}, \mathrm{MnC}$ \\
\hline & & $\mathrm{Bt}$ & $32-87$ & LCS & $\mathrm{C}, \mathrm{GR}$ to $\mathrm{PE}, \mathrm{QU}$ & MA & 7.5YR7/8 & $\mathrm{HP}, \mathrm{FeC}, \mathrm{MnC}$ \\
\hline & & $\mathrm{Cv}$ & $87-150+$ & LCS & F to $\mathrm{C}, \mathrm{GR}$ to $\mathrm{PE}, \mathrm{QU}$ & MA & 10YR7/8 (2.5YR4/8) & $\mathrm{HP}, \mathrm{FeC}, \mathrm{MnC}$ \\
\hline & F5 & A1 & $0-13$ & SL & F, GR, QU & MO, FI, GR & $5 Y R 4 / 4$ & $\mathrm{~N}$ \\
\hline & & $\mathrm{A} 2$ & $13-22$ & SCL & $\mathrm{C}, \mathrm{PE}, \mathrm{GN}$ and $\mathrm{QU}$ & $\mathrm{MO}, \mathrm{FI}, \mathrm{SB}$ & $5 Y R 5 / 6$ & $\mathrm{~N}$ \\
\hline & & Bt1 & $22-50 / 65$ & SCL & $\mathrm{F}, \mathrm{GR}, \mathrm{GN}$ and $\mathrm{QU}$ & WE, FI, SB & $5 Y R 4 / 8$ & $\mathrm{~N}$ \\
\hline & & $\mathrm{Bt} 2$ & $50 / 65-85$ & $\mathrm{SCL}$ & $\mathrm{C}, \mathrm{GR}$ to $\mathrm{PE}, \mathrm{GN}$ & WE, ME, AB & $5 \mathrm{YR} 5 / 8$ & $\mathrm{~N}$ \\
\hline & & $\mathrm{Cv}$ & $85-150+$ & SCL & F, PE, GN & MA & 7.5YR7/8 (2.5YR5/6) & SP \\
\hline \multirow[t]{11}{*}{ Ikire } & C6 & Ap & $0-18$ & LS & F, GR, QU & MO, ME, GR and SB & $2.5 \mathrm{YR} 2 / 4$ & $\mathrm{~N}$ \\
\hline & & A & $18-30$ & LS & $\mathrm{F}, \mathrm{GR}, \mathrm{QU}$ & $\mathrm{MO}, \mathrm{FI}$ to $\mathrm{ME}, \mathrm{SB}$ & $5 Y R 4 / 4$ & $\mathrm{~N}$ \\
\hline & & B & $30-50$ & SL & None & WE, FI to ME, AB & $5 Y R 4 / 6$ & $\mathrm{~N}$ \\
\hline & & $\mathrm{Bt}$ & $50-88$ & $\mathrm{SCL}$ & None & WE, FI, AB & $2.5 \mathrm{YR} 4 / 6$ & $\mathrm{~N}$ \\
\hline & & $\mathrm{Cv}$ & $88-150+$ & $\mathrm{C}$ & None & MA & 7.5YR7/8 (2.5YR4/6) & SP \\
\hline & F6 & A & $0-10$ & $\mathrm{~L}$ & None & WE to MO, VF, GR & $2.5 \mathrm{YR} 4 / 2$ & $\mathrm{~N}$ \\
\hline & & $\mathrm{AB}$ & $10-25$ & SL & None & WE, FI, SB & $10 \mathrm{YR} 4 / 6$ & $\mathrm{~N}$ \\
\hline & & B1 & $25-44$ & LS & None & WE, FI, AB & 10YR6/4 & $\mathrm{N}$ \\
\hline & & B2 & $44-65$ & SL & None & WE, ME, SB & $5 Y 7 / 4(2.5 Y 4 / 2,2.5 Y 3 / 1)$ & $\mathrm{MnC}$ \\
\hline & & $\mathrm{BCg}$ & $65-80$ & CL & None & WE, ME, MA to SB & $5 Y 7 / 3(2.5 Y 6 / 6)$ & $\mathrm{FeC}, \mathrm{MnC}$ \\
\hline & & $\mathrm{Cg}$ & $80-150+$ & SCL & None & MA & $5 Y 6 / 3(10 Y R 6 / 8)$ & $\mathrm{FeC}$ \\
\hline
\end{tabular}

$\dagger \quad$ C, cropland; F, forest. $\$$ SL, sandy loam; SC, sandy clay; SL, sandy loam; L, loam; SCL, sandy clay loam; C,clay; CL, cay loam; LS, loamy sand.

$\S \quad \mathrm{F}$, few; C, common; M, many; A, abundant; GR, gravel; PE, pebble; CO, cobble; WR, weathered rock; QU, quartz; GN, gneiss.

- WE, weak; MO, moderate; ST, strong; FI, fine; ME, medium; CO, coarse; CR, crumb; COL, columnar; GR, granular;

$\mathrm{AB}$, angular blocky; SB, subangular blocky; SG, single grain; MA, massive; RS, rock structure.

†† Based on Munsell color chart.

$\dagger \dagger$ N, none; FeC, Fe concretion; MnC, Mn concretion; SFeC, soft Fe concretion; SMnC, soft Mn concretion; SP, soft plinthite; HP, hard plinthite. 
in the upper horizons. Egbeda, Iwo, Iregun, and Ikire series showed a sandy to loamy texture complex in the upper horizons. The examined soil series generally had a crumbly or granular structure in the surface horizon, while angular or subangular blocky structure in the B horizon followed by structureless (massive) $\mathrm{C}$ horizons.

\section{Soil phosphorus and potassium}

Available $\mathrm{P}$ and Exchangeable $\mathrm{K}$ content tended to decrease with soil depth; available $\mathrm{P}$, in particular, became very low in the lower horizons below $50 \mathrm{~cm}$ (Fig. 3 and Fig. 4). Available $\mathrm{P}$ and exchangeable $\mathrm{K}$ was generally higher in the cropland than in the forest (Fig. 3 and Fig. 4). Available $\mathrm{P}$ and exchangeable $\mathrm{K}$ significantly correlated with exchangeable $\mathrm{Ca}$ and $\mathrm{Mg}$ in the forest, whereas no correlation was found in the cropland (Table 2).

Available $\mathrm{P}$ and exchangeable $\mathrm{K}$ can be maintained and improved by the application of fertilizer in this study soil. These results are supported by Sanchez et al. (1982) who reported that available phosphorus and exchangeable potassium could be maintained with the application of fertilizer. In general, application of $\mathrm{P}$ fertilizer is essential to improve crop productivity in highly weathered tropical soils, which have high active iron and iron oxide content, and thus high $\mathrm{P}$ fixation capacity and low $\mathrm{P}$ availability (Sahrawat et al. 2001). Preferential accumulation of available $\mathrm{P}$ in the upper horizons of the Iregun and Ikire series in comparison to those of Egbeda and Iwo series suggests that surface soil with P accumulation was washed away from the upper slope to the lower slope because of surface runoff and soil erosion in cropland. Soil erosion rates in the croplands at IITA headquarters are relatively high; estimated as 3-7 Mg ha ${ }^{-1}$ year $^{-1}$ in the maize fields and $7 \mathrm{Mg} \mathrm{ha}^{-1}$ year $^{-1}$ in the cassava fields (Junge et al. 2010). Furthermore, the majority of the $\mathrm{P}$ fertilizer is absorbed by Fe oxides in highly weathered soil. Fe oxide-rich upper slope soil has higher P fertilizer sorption than the lower slope. Over the majority of the slope position, exchangeable $\mathrm{K}$ was higher for the cropland than the forest (Fig. 4). Exchangeable
$\mathrm{K}$ levels increased rapidly after burning but decreased as fast because reaching (Sanchez et al. 1983). Exchangeable potassium accumulated through the application of chemical fertilizer and was quickly lost due to leaching.

\section{Soil organic carbon and nitrogen}

Organic $\mathrm{C}$ content in the studied pedons was highest in the uppermost horizons and decreased sharply with depth (Fig. 5). The surface horizons of the forest had a slightly higher organic $\mathrm{C}$ content than that of the cropland (Fig. 5). The organic $\mathrm{C}$ content followed the same soil profile distribution trend as that of the total $\mathrm{N}$ content, as indicated by a strong positive correlation coefficient between the organic $\mathrm{C}$ and total $\mathrm{N}$ contents (Table 2).

The $\mathrm{C} / \mathrm{N}$ ratio generally decreased with increasing soil depth and showed an extremely low ratio in the subsoil horizons of the Ekiti and Egbeda series (Fig. 5). The surface horizons, the forest had a significantly lower $\mathrm{C} / \mathrm{N}$ ratio than the cropland (Table 3), while an opposite trend was observed for some subsoil horizons of the Iwo and Ikire series.

Land clearing and subsequent crop cultivation often results in the loss of organic $\mathrm{C}$ in the soil in the tropics (Abe et al. 2007c, 2009a, Detwiler 1986, Don et al. 2011) because of rapid decomposition of organic matter under the tropical climate (Jenkinson \& Ayanaba 1977). In contrast, the soils of the forest had approximately $10 \mathrm{mg} \mathrm{kg}^{-1}$ higher organic C content than cropland (Thomas et al. 1992). In this study, however, organic $\mathrm{C}$ content in the surface horizon was only $5 \mathrm{mg} \mathrm{kg}^{-1}$ higher in the forest than in the cropland (Table 3). Crop residue recycling and an improved off-season fallow system partially and intermittently implemented to the cropland may prevent accelerated decomposition of soil organic matter from under crop cultivation (Juo \& Lal 1977, Juo et al. 1995a, 1995b, 1996). Although past authors have not mentioned it, all IITA croplands were well developed and demarcated based on the contour lines at the time IITA started its research activities. This contour based land development and demarcation might have contributed

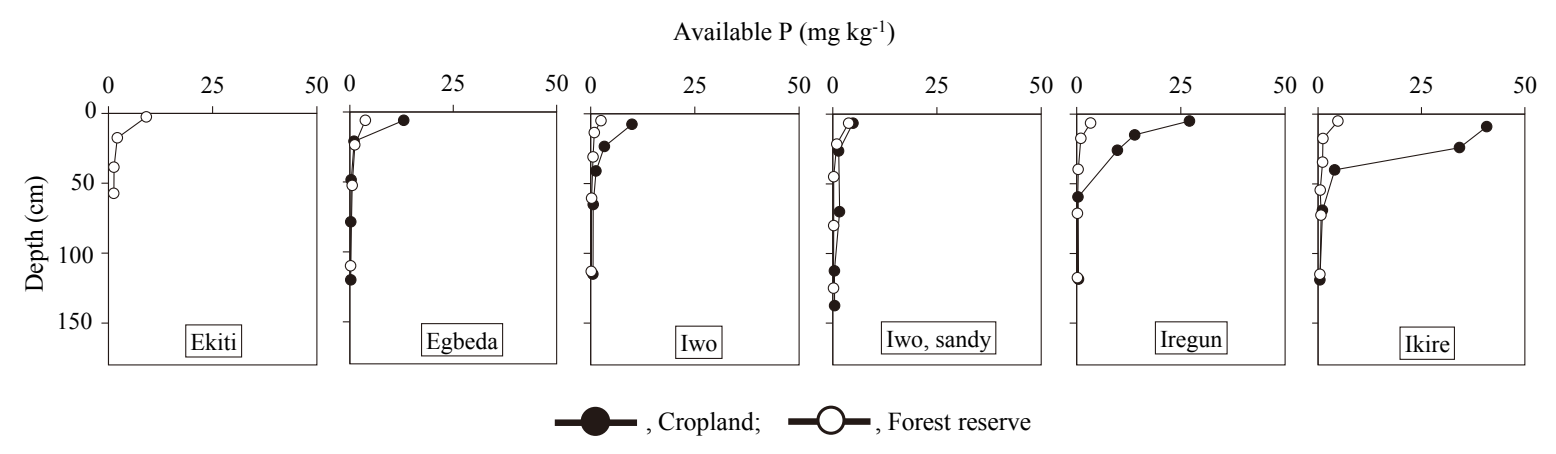

Fig. 3. Comparison of available phosphorus content in the soil series between the cropland and the forest. 


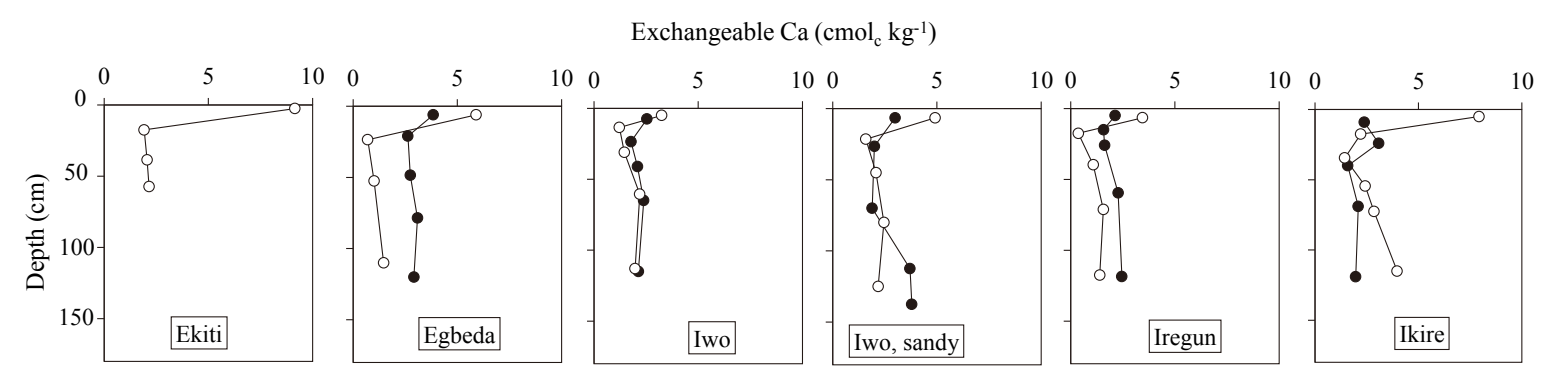

Exchangeable $\mathrm{Mg}\left(\mathrm{cmol}_{\mathrm{c}} \mathrm{kg}^{-1}\right)$

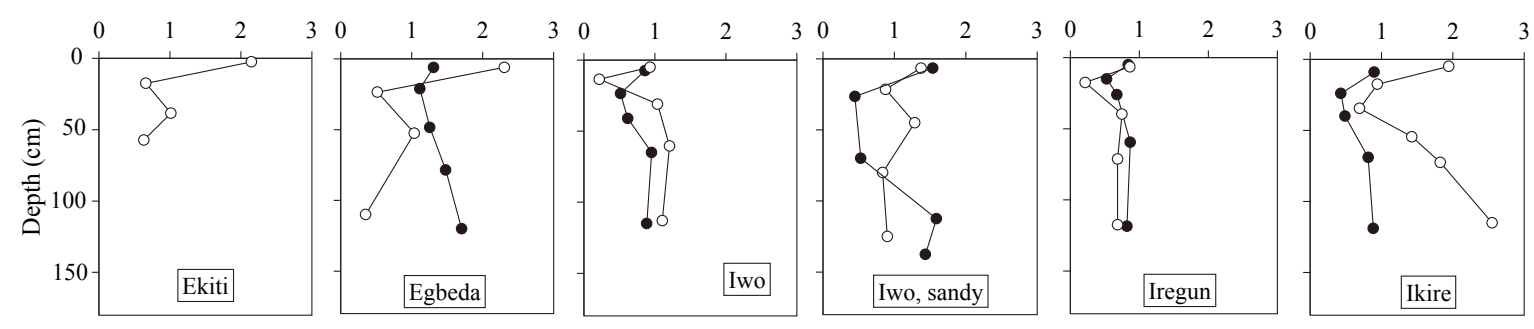

Exchangeable $\mathrm{K}\left(\mathrm{cmol}_{\mathrm{c}} \mathrm{kg}^{-1}\right)$

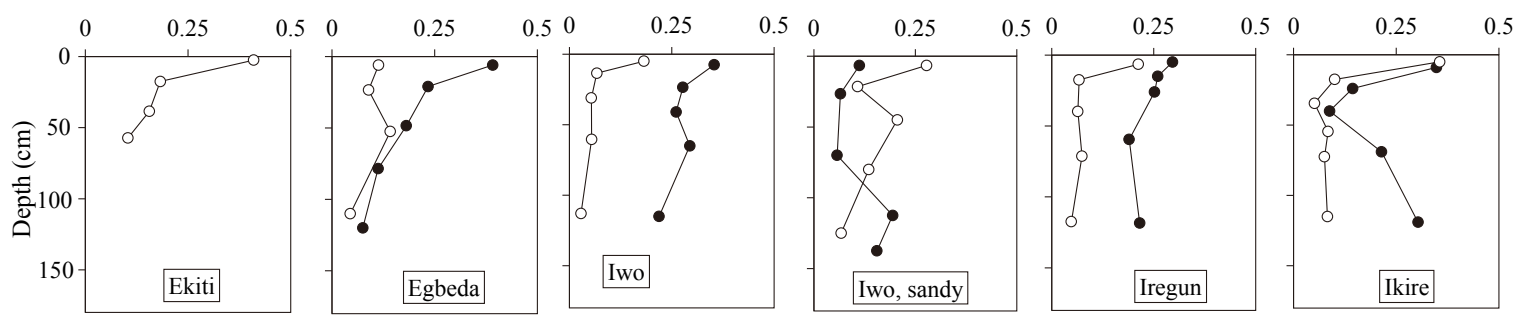

Exchangeable acidity $\left(\mathrm{cmol}_{\mathrm{c}} \mathrm{kg}^{-1}\right)$

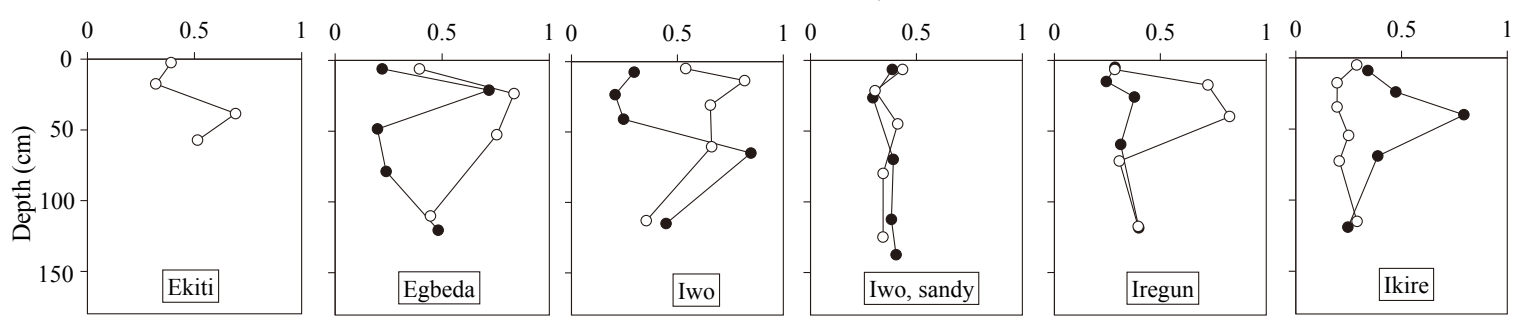

Base saturation (\%)

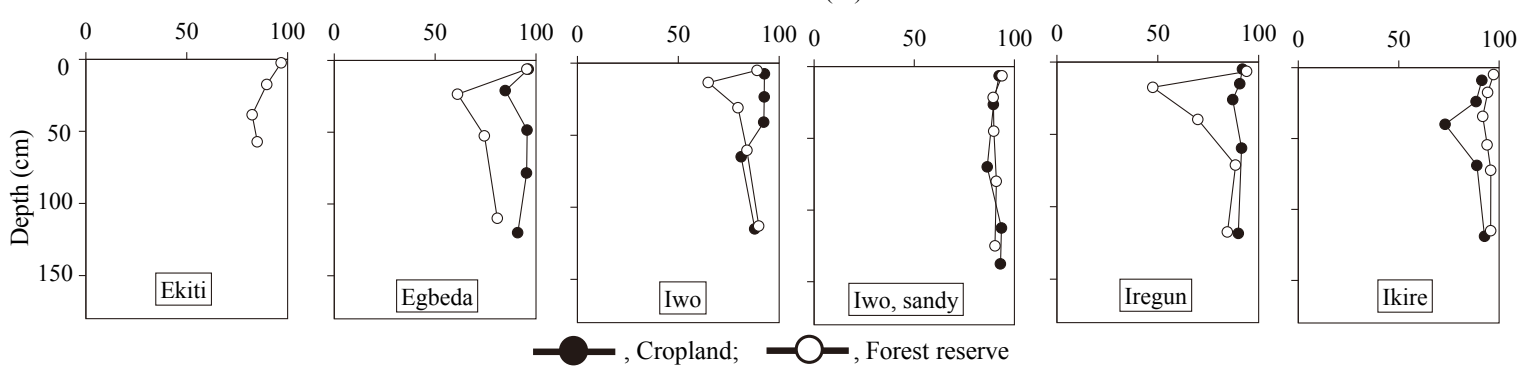

Fig. 4. Comparison of the contents of exchangeable bases (calcium, magnesium, and potassium), exchangeable acidity, and base saturation in the soil profiles between the cropland and the forest.

to the prevention of soil degradation over the last 30 years. Secondary forests usually store less organic $\mathrm{C}$ than primary forests, underlining the importance of primary forests for C stores (Don et al. 2011). The forest area was a pattern of secondary forest, cocoa plantation, and arable crops in rotation with bush regrowth before IITA was established (Moormann et al. 1975), and soil organic C content might have been loosed due to traditional shifting cultivation. The long-term (30 years) natural fallow could establish secondary forest, but might not greatly recover soil organic 
Table 2. Correlation matrix of selected physicochemical parameters

\begin{tabular}{|c|c|c|c|c|c|c|c|c|c|c|c|}
\hline Cropland & $\mathrm{pH}_{\text {water }}$ & $\mathrm{pH} \mathrm{KCl}_{\mathrm{K}}$ & $\mathrm{OC}$ & $\mathrm{TN}$ & $\mathrm{C} / \mathrm{N}$ & Av.P & Ex.Ca & Ex.Mg & Ex.K & Ex.Acidity & ECEC \\
\hline $\mathrm{pHKCl}$ & $0.647^{* *}$ & & & & & & & & & & \\
\hline OC & 0.360 & 0.165 & & & & & & & & & \\
\hline $\mathrm{TN}$ & 0.266 & 0.059 & $0.970^{* *}$ & & & & & & & & \\
\hline $\mathrm{C} / \mathrm{N}$ & $0.479^{*}$ & 0.208 & $0.813^{* *}$ & $0.663^{* *}$ & & & & & & & \\
\hline Av.P & 0.349 & 0.189 & $0.654^{* *}$ & $0.528^{* *}$ & $0.797^{* *}$ & & & & & & \\
\hline Ex.Ca & -0.024 & 0.284 & 0.272 & 0.364 & -0.109 & 0.009 & & & & & \\
\hline Ex.Mg & -0.080 & 0.325 & 0.031 & 0.117 & -0.313 & -0.261 & $0.769^{* *}$ & & & & \\
\hline Ex.K & 0.285 & 0.362 & $0.397^{*}$ & 0.329 & $0.459^{*}$ & 0.363 & -0.018 & -0.084 & & & \\
\hline Ex.Acidity & -0.305 & -0.295 & -0.170 & -0.115 & -0.224 & -0.111 & -0.057 & -0.021 & -0.219 & & \\
\hline ECEC & -0.084 & 0.304 & 0.180 & 0.277 & -0.207 & -0.094 & $0.951^{* *}$ & $0.898^{* *}$ & -0.004 & 0.099 & \\
\hline Base sat. & 0.163 & 0.392 & 0.240 & 0.233 & 0.114 & 0.068 & $0.478^{*}$ & $0.436^{*}$ & 0.263 & $-0.857^{* *}$ & 0.371 \\
\hline Forest & $\mathrm{pH}_{\text {water }}$ & $\mathrm{pH} \mathrm{KCl}_{\mathrm{K}}$ & $\mathrm{OC}$ & $\mathrm{TN}$ & $\mathrm{C} / \mathrm{N}$ & Av.P & Ex.Ca & Ex.Mg & Ex.K & Ex.Acidity & ECEC \\
\hline $\mathrm{pHKCl}$ & $0.792^{* *}$ & & & & & & & & & & \\
\hline OC & $0.491^{* *}$ & $0.596^{* *}$ & & & & & & & & & \\
\hline $\mathrm{TN}$ & $0.458^{*}$ & $0.554^{* *}$ & $0.984^{* *}$ & & & & & & & & \\
\hline $\mathrm{C} / \mathrm{N}$ & $0.474^{* *}$ & $0.474^{* *}$ & $0.716^{* *}$ & $0.626^{* *}$ & & & & & & & \\
\hline Av.P & $0.590^{* *}$ & $0.632^{* *}$ & $0.935^{* *}$ & $0.892^{* *}$ & $0.638^{* *}$ & & & & & & \\
\hline Ex.Ca & $0.706^{* *}$ & $0.737^{* *}$ & $0.846^{* *}$ & $0.804^{* *}$ & $\mathbf{0 . 5 7 8}^{* *}$ & $0.873^{* *}$ & & & & & \\
\hline Ex.Mg & $0.631^{* *}$ & $0.420^{*}$ & $0.469^{*}$ & $0.426^{*}$ & $0.431^{*}$ & $0.476^{* *}$ & $0.766^{* *}$ & & & & \\
\hline Ex.K & $0.499^{* *}$ & $0.565^{* *}$ & $0.815^{* *}$ & $0.797^{* *}$ & $0.497^{* *}$ & $0.860^{* *}$ & $0.805^{* *}$ & $0.438^{*}$ & & & \\
\hline Ex.Acidity & $-0.743^{* *}$ & $-0.679^{* *}$ & -0.012 & 0.047 & -0.149 & -0.146 & -0.362 & $-0.396^{*}$ & -0.164 & & \\
\hline ECEC & $0.677^{* *}$ & $0.659^{* *}$ & $0.821^{* *}$ & $0.781^{* *}$ & $0.574^{* *}$ & $0.836^{* *}$ & $0.989^{* *}$ & $0.840^{* *}$ & $0.775^{* *}$ & -0.312 & \\
\hline Base sat. & $0.716^{* *}$ & $0.682^{* *}$ & 0.245 & 0.205 & 0.208 & 0.323 & $0.594^{* *}$ & $0.638^{* *}$ & $0.377^{*}$ & $-0.830^{* *}$ & $0.578^{* *}$ \\
\hline
\end{tabular}

$* P<0.05, * * P<0.01 . \quad N=25$ (Cropland), 29 (Forest)

Bold letters show significant indicator of the Forest only.
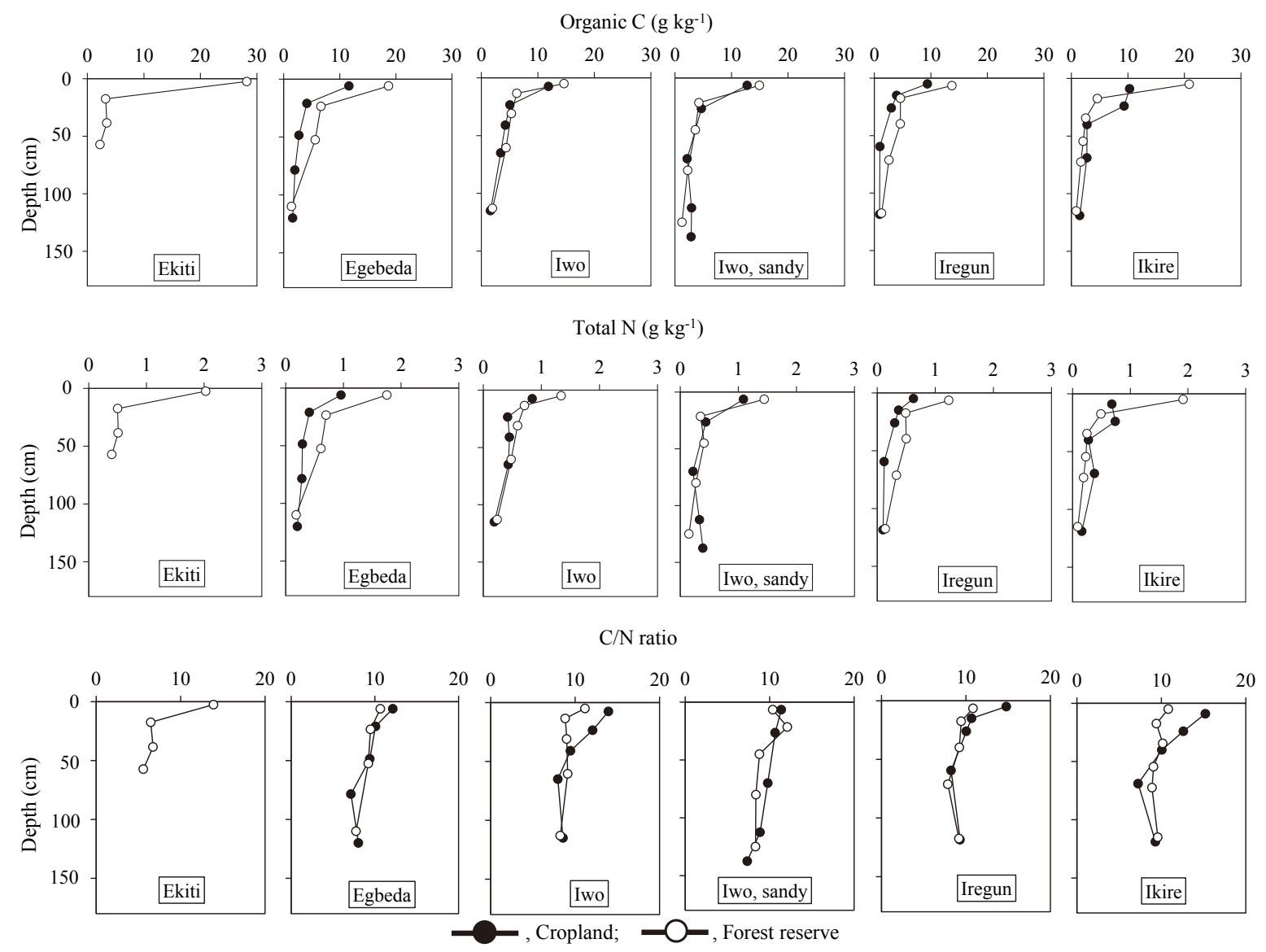

Fig. 5. Comparison of organic carbon and total nitrogen contents in the soil profiles between the cropland and the forest. 
Table 3. Soil nutrients in surface, upper ( $>50 \mathrm{~cm})$ and lower $(<50 \mathrm{~cm})$ soil at Cropland, Forest and reference survey

\begin{tabular}{|c|c|c|c|c|c|c|c|c|c|c|c|c|c|}
\hline & \multirow{2}{*}{$\begin{array}{l}\text { Bulk density } \\
\left(\mathrm{Mg} \mathrm{m}^{-3}\right)\end{array}$} & \multirow{2}{*}{$\begin{array}{l}\text { Compactness } \\
\left(\mathrm{kg} \mathrm{m}^{-2}\right)\end{array}$} & \multicolumn{2}{|c|}{$\mathrm{pH}$} & \multirow[t]{2}{*}{ Organic-C } & \multirow{2}{*}{$\begin{array}{r}\text { Total N } \\
\left(\mathrm{g} \mathrm{kg}^{-1}\right)\end{array}$} & \multirow[t]{2}{*}{$\mathrm{C} / \mathrm{N}$} & \multirow{2}{*}{$\frac{\text { Available } \mathrm{P}^{\dagger \dagger}}{\left(\mathrm{mg} \mathrm{kg}^{-1}\right)}$} & \multicolumn{4}{|c|}{ Exchangeable $\left(\mathrm{cmolc} \mathrm{kg}^{-1}\right)$} & \multirow{2}{*}{$\begin{array}{c}\text { Base saturation } \\
(\%)\end{array}$} \\
\hline & & & water & $\mathrm{KCl}$ & & & & & $\mathrm{Ca}$ & $\mathrm{Mg}$ & $\mathrm{K}$ & Acidity & \\
\hline \multicolumn{14}{|c|}{ Surface horizon (top soil horizon) } \\
\hline Cropland & $1.37 \mathrm{a}$ & $2.12 \mathrm{~b}$ & $6.59 \mathrm{a}$ & $5.73 \mathrm{a}$ & $11.19 \mathrm{a}$ & $0.84 \mathrm{a}$ & $13.49 \mathrm{~b}$ & $19.13 \mathrm{a}$ & $2.78 \mathrm{a}$ & $1.09 \mathrm{a}$ & $0.30 \mathrm{a}$ & $0.31 \mathrm{~b}$ & $92.92 \mathrm{a}$ \\
\hline Forest & $1.19 \mathrm{a}$ & $0.80 \mathrm{ab}$ & $6.34 \mathrm{a}$ & $5.69 \mathrm{a}$ & 16.57 a & $1.54 \mathrm{~b}$ & 10.77 a & $3.63 \mathrm{a}$ & $5.09 \mathrm{a}$ & $1.48 \mathrm{a}$ & $0.23 \mathrm{a}$ & $0.39 \mathrm{~b}$ & 93.93 a \\
\hline Reference $^{\dagger}$ & $1.30 \mathrm{a}$ & $0.53 \mathrm{a}$ & $6.43 \mathrm{a}$ & $5.77 \mathrm{a}$ & $12.47 \mathrm{a}$ & $1.23 \mathrm{ab}$ & $10.00 \mathrm{a}$ & $13.57 \mathrm{a}$ & $3.42 \mathrm{a}$ & $1.05 \mathrm{a}$ & $0.25 \mathrm{a}$ & $0.14 \mathrm{a}$ & $97.12 \mathrm{a}$ \\
\hline \multicolumn{14}{|c|}{ Upper horizon (Average of 0-50 cm horizons) } \\
\hline Cropland & $1.54 \mathrm{~b}$ & $8.33 \mathrm{a}$ & $6.40 \mathrm{a}$ & $5.48 \mathrm{a}$ & $6.31 \mathrm{a}$ & $0.53 \mathrm{a}$ & $11.30 \mathrm{~b}$ & 10.27 a & $2.35 \mathrm{a}$ & $0.81 \mathrm{a}$ & $0.22 \mathrm{a}$ & $0.37 \mathrm{ab}$ & $89.77 \mathrm{ab}$ \\
\hline Forest & $1.43 \mathrm{ab}$ & $7.48 \mathrm{a}$ & $5.80 \mathrm{a}$ & $5.00 \mathrm{a}$ & $8.15 \mathrm{a}$ & $0.80 \mathrm{a}$ & $9.89 \mathrm{ab}$ & $1.59 \mathrm{a}$ & $2.51 \mathrm{a}$ & $1.03 \mathrm{a}$ & $0.13 \mathrm{a}$ & $0.51 \mathrm{~b}$ & $82.44 \mathrm{a}$ \\
\hline Reference $^{\dagger}$ & $1.36 \mathrm{a}$ & $1.72 \mathrm{a}$ & $6.31 \mathrm{a}$ & $5.42 \mathrm{a}$ & $8.48 \mathrm{a}$ & $0.82 \mathrm{a}$ & $9.42 \mathrm{a}$ & $7.70 \mathrm{a}$ & $3.16 \mathrm{a}$ & $1.02 \mathrm{a}$ & $0.19 \mathrm{a}$ & $0.17 \mathrm{a}$ & $95.83 \mathrm{~b}$ \\
\hline \multicolumn{14}{|c|}{ Lower horizon (Average of below $50 \mathrm{~cm}$ horizons) } \\
\hline Cropland & $1.63 \mathrm{~b}$ & $19.21 \mathrm{a}$ & $6.19 \mathrm{a}$ & $5.52 \mathrm{~b}$ & $2.19 \mathrm{a}$ & $0.26 \mathrm{a}$ & $8.51 \mathrm{ab}$ & $0.60 \mathrm{a}$ & $2.52 \mathrm{a}$ & $1.03 \mathrm{a}$ & $0.20 \mathrm{a}$ & $0.38 \mathrm{ab}$ & $90.74 \mathrm{ab}$ \\
\hline Forest & $1.59 \mathrm{~b}$ & $21.73 \mathrm{a}$ & $5.52 \mathrm{a}$ & $4.86 \mathrm{a}$ & $2.83 \mathrm{a}$ & $0.32 \mathrm{a}$ & $8.74 \mathrm{~b}$ & $0.34 \mathrm{a}$ & $1.95 \mathrm{a}$ & $1.09 \mathrm{a}$ & $0.08 \mathrm{a}$ & $0.46 \mathrm{~b}$ & $85.73 \mathrm{a}$ \\
\hline Reference $^{\dagger}$ & $1.46 \mathrm{a}$ & $3.36 \mathrm{a}$ & $6.09 \mathrm{a}$ & $5.22 \mathrm{ab}$ & $3.08 \mathrm{a}$ & $0.41 \mathrm{a}$ & $7.25 \mathrm{a}$ & $2.96 \mathrm{a}$ & $2.53 \mathrm{a}$ & $0.84 \mathrm{a}$ & $0.16 \mathrm{a}$ & $0.17 \mathrm{a}$ & $95.44 \mathrm{~b}$ \\
\hline
\end{tabular}

${ }^{\dagger}$ Moormann et al. (1975) † Available P = Bray 1-P.

Means in columns followed by the same letter are not significant at $P<0.05$, using Scheffe's test.

$N=5$ (Cropland and Forest), 3 (Reference)

C stocks.

Despite the frequent application of $\mathrm{N}$ fertilizer to the cropland for the past 30 years, the total $\mathrm{N}$ content, especially in the upper horizons, was generally found to be lower in the cropland than in the forest (Fig. 5), and significantly $(P<0.05)$ lower in the cropland surface horizons than in the forest (Table 3). This suggests that a major portion of mineral $\mathrm{N}$ derived from the fertilizer was lost from the surface horizons through plant uptake, leaching and denitrification (Arpra \& Juo 1982, Cobo et al. 2002, Van der Kruijs et al. 1988). The strong correlation of total $\mathrm{N}$ with organic $\mathrm{C}$ suggests that most $\mathrm{N}$ is stored in soil organic matter (Table 2). The greater $\mathrm{N}$ immobilization by trees and its accumulation in soil organic matter is prominent in the forest.

\section{Soil chemical properties}

The soils at the study site showed slight or moderate acidity (Fig. 6). Soil $\mathrm{pH}_{\text {water }}$ was highest in the surface horizons and decreased with depth while increasing slightly at the lower horizons. Soil $\mathrm{pH}_{\text {water }}$ was higher throughout the profile in the cropland than in the forest except for the upper horizons of the Ikire series. Soil $\mathrm{pH}_{\mathrm{KCl}}$ generally represented the same trend of soil $\mathrm{pH}_{\text {water. }}$ Soil $\mathrm{pH}_{\mathrm{KCl}}$ of the cropland was significantly higher $(P<0.05)$ than in forest at the lower horizons. The soil $\mathrm{pH}_{\text {water }}$ was negatively correlated with exchange acidity but positively correlated with exchangeable $\mathrm{Ca}$ and $\mathrm{K}$ and base saturation percentage (Table 2).

Generally, exchangeable $\mathrm{Ca}$ was found to be accumulated in the surface horizons (Fig. 4). Some subsoil horizons also showed accumulation of exchangeable $\mathrm{Ca}$. The present results indicated that the surface horizons in the croplands had lower exchangeable Ca content than those in the forest (Fig. 4). Some subsoil horizons for the Iwo series sandy phase, Egbeda, Iwo, and Iregun series showed lower exchangeable $\mathrm{Ca}$ content in the forest than in the cropland. Most horizons of the Iwo series sandy phase, the subsoil horizons of the Iregun series, and the surface and lower horizons of the Ikire series had relatively similar values between forest and cropland. Base saturation was especially low in the subsurface soil horizons of the forest for the Egbeda, Iwo, and Iregun series, and those of the cropland for the Egbeda and Ikire series.

The lower soil $\mathrm{pH}$ in the forest than those in the cropland and the reference survey suggested that soil acidification occurred in the forest (Fig. 6 and Table 3). In the forest, soil acidification was associated with increased exchangeable acidity and decreased percentages of base saturation (Table 2 and Fig. 4). In general, reforestation and forest restoration including natural vegetation regrowth during a long-term fallow result in an increase in exchangeable acidity and a decrease in exchangeable $\mathrm{Ca}, \mathrm{Mg}$, and $\mathrm{K}$ content owing to redistribution of these bases from the soil to biomass pools (Jackson et al. 2005). The higher contents of exchangeable $\mathrm{Ca}$ in the surface horizons of the forest compared with those of the cropland but opposite trend in the subsoil horizons suggested that the bases were taken up from the subsoil by trees with deep root systems and that the bases assimilated into the tree biomass eventually accumulate in the surface horizons through litter fall (Dijkstra \& Smiths 2002, Vanlauwe et al. 2005). This mechanism also explains why soil acidification is more severe in the subsoil horizons than the surface horizons. Trees also produce 

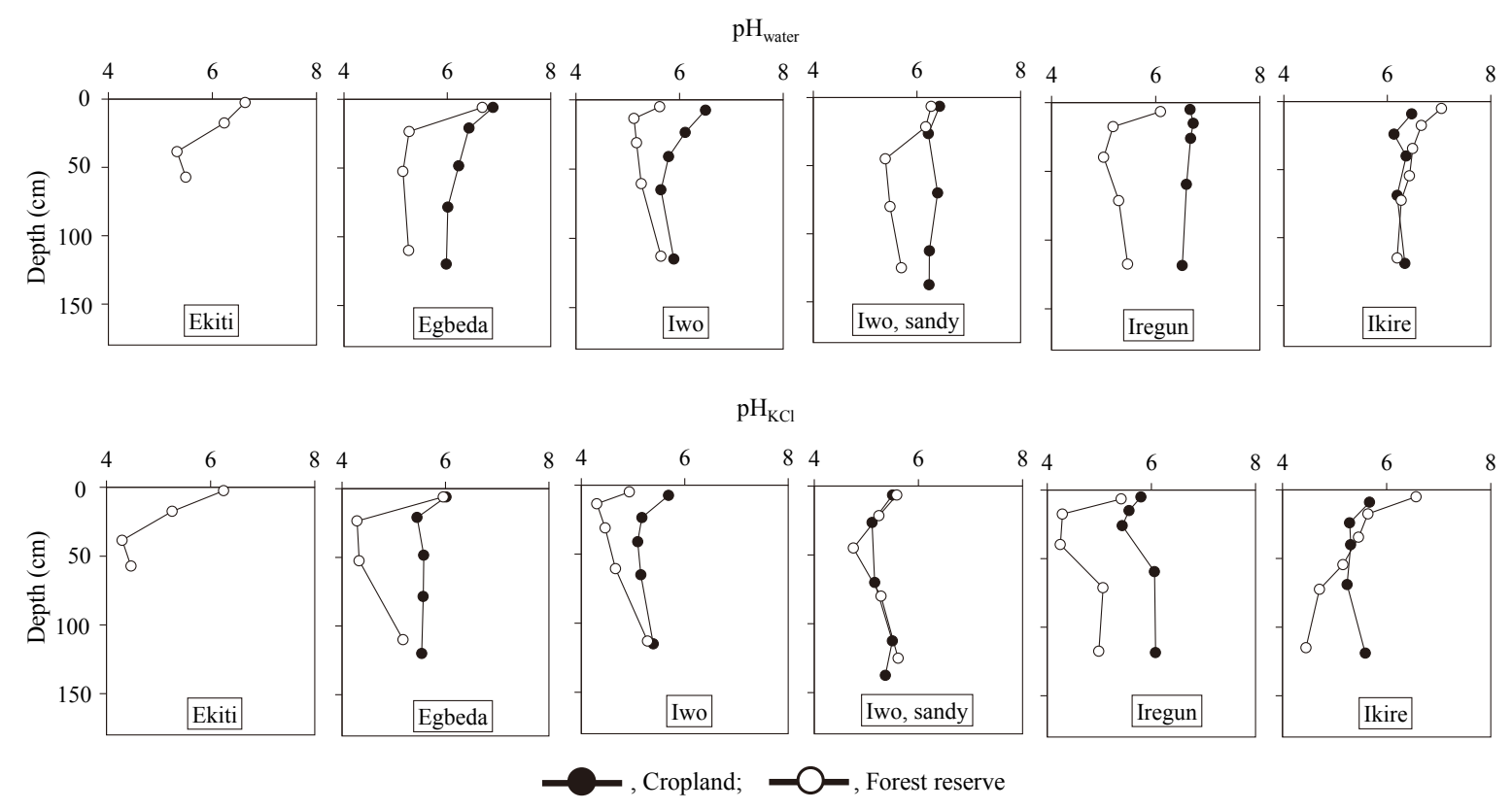

Fig. 6. Comparison of soil $\mathrm{pH}$ with water and $1 \mathrm{M}$ potassium chloride in the soil profiles between the cropland and the forest.

acidic canopy leachates and litter decomposition products, which cause further soil acidification (Jackson et al. 2005). Exchangeable $\mathrm{Ca}$ content in the surface horizons of the forest suggested that accumulation of soil organic matter enhanced amounts of exchangeable bases as well as cation exchange capacity, as reported by Juo and Lal (1977) and Merckx et al. (2001). Input of base cations as a component of organic matter could alleviate soil acidification in the surface soils and would explain the lower acidification in the surface soil than the subsoil in the forest.

In the cropland, exchangeable cations have remained at the same level as the reference survey, and would prevent topsoil acidification (Table 3 ). In general, $\mathrm{N}$ fertilizers affect soil acidity because of the preferential uptake of nitrate-N to bases by most crops and the excretion of hydroxide ions to balance the charge reduces acidity (Jolley \& Pierre 1977, Pierre et al. 1971). Juo et al. (1995a, 1995b, 1996) reported soil acidification followed by a considerable decline of exchangeable $\mathrm{Ca}$ in the topsoil horizons of the Egbeda series under continuous maize-based systems, which would arise from nutrient removal by crop harvest (Jaiyeoba 1995, Sharma et al. 2009), application of ammoniacal fertilizers and nitrification of applied N (Stumpe \& Vlek 1991). In this study, the application of triple super phosphate containing $\mathrm{Ca}(12 \%, \mathrm{w} / \mathrm{w})$ may have helped to replenish the exchangeable $\mathrm{Ca}$ and prevent acidification in the soil of the cropland.

\section{Soil compaction}

Bulk density was lowest in the surface horizons and became higher with depth. It became relatively constant in soil horizons below $50 \mathrm{~cm}$ (Fig. 7). The soils in the surface horizons of cropland had a slightly higher bulk density than those in the forest. This trend was prominent in the upper horizons of the Egbeda series and all horizons in the Iwo series sandy phase. Soil penetrometer readings revealed the same trend as the bulk density data (Fig. 7). The penetrometer readings showed a higher value with soil depth and were in the order of cropland-to-forest in the upper horizons. Higher soil compaction was observed in the deepest horizons of the Egbeda series in the forest and the Iregun series in the cropland. While soil bulk density and compactness in the cropland was significantly higher than that of reference data in the Upper and Lower horizons and the Surface horizon (Table 3), soil structure disruption in the cropland was not detectable in the field observation of soil morphological characteristics (Table 1).

IITA widely applies mechanical tillage in land preparation every cropping season, which disrupts soil structure and accelerates soil compaction. However, the weak development of crumb or granular structure in the sandy topsoils of the study site would make it difficult to find signs of soil structure disruption in the field. Soil compaction during crop cultivation at IITA has been reported in the Egbeda series (Juo \& Lal 1977, Juo et al. 1996) as soil structural stability is usually very poor in kaolinitic Alfisols (Juo et al. 1995b, Kang \& Spain 1996). Reduced mechanical tillage, the application of surface mulch, and the insertion of organic matter would all be useful measures to enhance soil structural stability and prevent soil compaction (Lal 1987). 

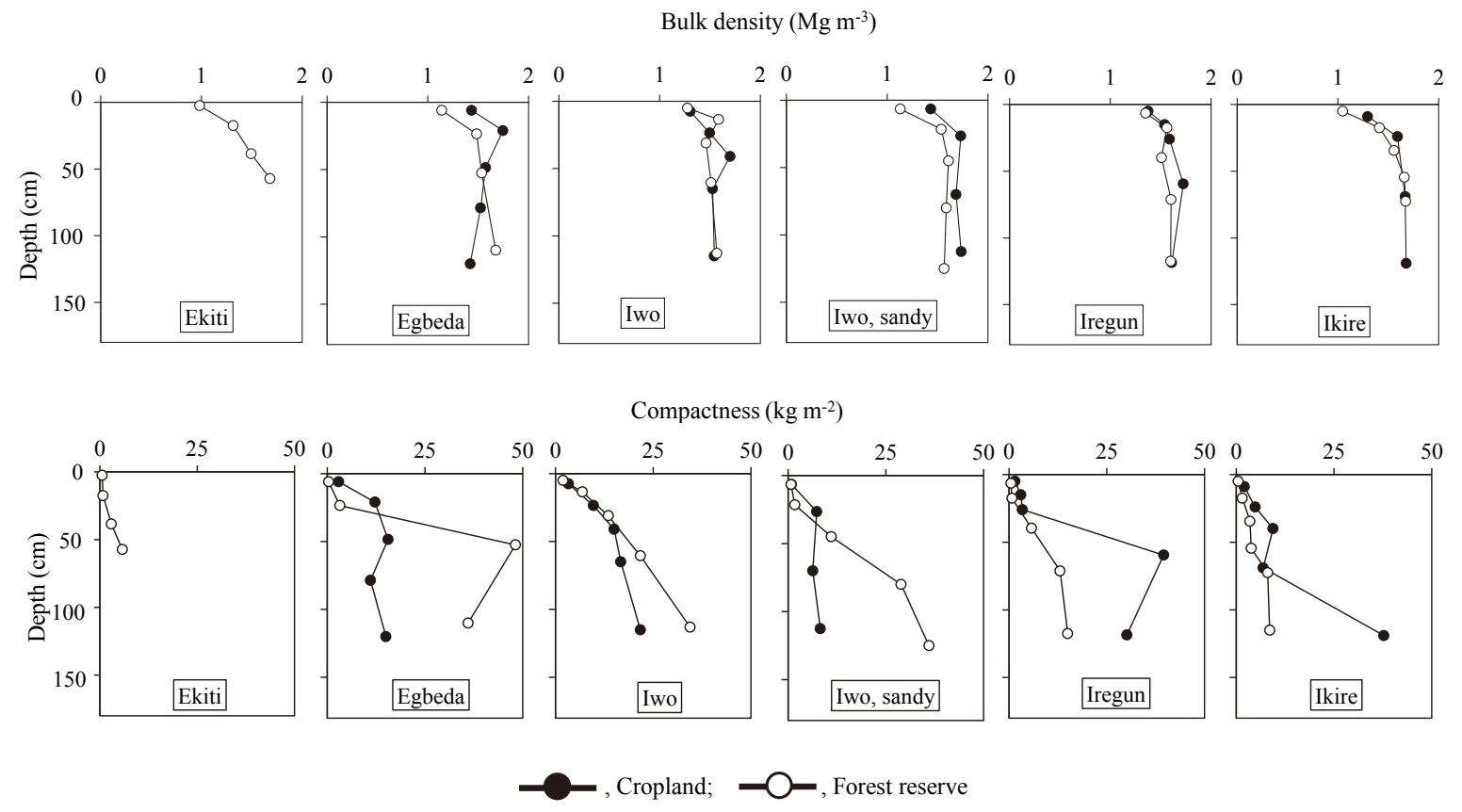

Fig. 7. Comparison of bulk density and soil hardness readings in the soil profiles between the cropland and the forest.

\section{Conclusions}

The present study examined the long-term changes in the physicochemical properties of between croplands and forest. Differences in soil fertility were unremarkable. It was concluded that soil fertility could be maintained with a long-term intensive and continuous crop farming system in a kaolinitic Alfisol soil over the inland valley toposequences of tropical Africa. The system requires appropriate fertilizer management and soil conservation measures such as soil erosion control and soil organic matter management. Further research is required to clarify the details of these systems. Major findings and suggestions are summarized as follows:

1) Available $P$ and exchangeable $K$ were higher in the surface horizons of the cropland than the forest, probably because of the application of fertilizer and developed cropland.

2) Soil organic $\mathrm{C}$ and total $\mathrm{N}$ contents were slightly lower in the surface horizons of the cropland than the forest, suggesting that soil organic matter was maintained by continuous crop farming.

3) Soil acidification was not severe in the upper horizons of the croplands, probably because of the application of triple super phosphate containing $\mathrm{Ca}$, which may have helped to replenish the exchangeable $\mathrm{Ca}$ in soil, while substantial acidification took place in the soil profiles of the forest, probably because of the preferential uptake of bases by trees and organic acid derived from litter decomposition. Exchangeable $\mathrm{Ca}$ accumulated in the surface horizons of the forest, which suggested that accumulation of soil organic matter enhanced the amount of exchangeable bases as well as cation exchange capacity.

4) Mechanical tillage may be thought to cause soil compaction in the upper horizons of the cropland, though the extent of soil compaction was minor and would not greatly affect crop production.

\section{Acknowledgments}

This work was funded by a Grant-in-Aid for the Specially Promoted Scientific Research from the Ministry of Education, Culture, Sports, Science and Technology of Japan (JSPS Grant-in-Aid No. 19002001 to TW). The authors are very thankful to IITA staff for supporting this study in their fields.

\section{References}

Abe, S.S. et al. (2006) Comprehensive assessment of the clay mineralogical composition of lowland soils in West Africa. Soil Sci. Plant Nutr., 52, 479-488.

Abe, S.S. et al. (2007a) Primary mineral characteristics of topsoil samples from lowlands in seven West African countries. Jpn. J. Trop. Agric., 51, 35-39.

Abe, S.S. (2007b) Soil development and fertility characteristics of inland valleys in the rain forest zone of Nigeria: Physicochemical properties and morphological features. Soil Sci. 
Plant Nutr., 51, 35-39.

Abe, S.S. et al. (2007c) Land-use effects on soil macro- and micronutrient status in tropical lowland zone of Bolivia. Grassl. Sci., 53, 33-38.

Abe, S.S. et al. (2009a) Effects of land-use change on chemical composition of soil organic matter in tropical lowland Bolivia. Grassl. Sci., 55, 104-109.

Abe, S.S. et al. (2009b) Soil development and fertility characteristics of inland valleys in the rain forest zone of Nigeria: Mineralogical composition and particle-size distribution. Pedosphere, 19, 505-514.

Abe, S.S. et al. (2009c) Physicochemical and morphological properties of termite (Macrotermes bellicosus) mounds and surrounding pedons on a toposequence of an inland valley in the southern Guinea savanna zone of Nigeria. Soil Sci. Plant Nutr., 55, 514-522.

Arora, Y. \& Juo, A.S.R. (1982) Leaching of fertilizer ions in a kaolinitic Ultisol in the high rainfall tropics: Leaching of nitrate in field plots under cropping and bare fallow. Soil Sci. Soc. Am. J., 46, 1212-1218.

Chazdon, R.L. (2008) Beyond deforestation: restoring forests and ecosystem services on degraded lands. Science, 320, 1458-1460.

Cobo J.G. et al. (2002) Nitrogen mineralization and crop uptake from surface-applied leaves of green manure species on a tropical volcanic-ash soil. Biol Fertil Soils, 36, 87 - 92.

Detwiler, R.P. (1986) Land use change and the global carbon cycle: the role of tropical soils. Biogeochemistry, 2, 67-93.

Dijkstra, F.A. \& Smiths M.M. (2002) Tree species effects on calcium cycling: The role of calcium uptake in deep soils. Ecosystems, 5, 385-398.

Don, A. et al. (2011) Impact of tropical land-use change on soil organic carbon stocks - a meta-analysis. Glob. Change Biol., 17, 1658-1670.

Egesi, C.N. et al. (2007) Evaluation of water yam (Dioscorea alata L.) germplasm for reaction to yam anthracnose and virus diseases and their effect on yield. J. Phytopathol., 155, 536-543.

Ekleme, F. et al. (2004) Impact of natural, planted (Puraria phaseoloides, Leucaena leucocephala) fallow and land-use intensity on weed seedling emergence pattern and density in cassava intercropped with maize. Agric. Ecosyst. Environ., 103, 581-593.

Ewel, J.J. (1986) Designing agricultural ecosystems for the humid tropics. Ann. Rev. Ecol. Syst., 17, 245-271.

Hall, J.B. \& Okali D.U.U. (1979) A structural and floristic analysis of woody fallow vegetation near Ibadan, Nigeria. $J$. Ecol., 67, 321-346.

IITA (1979) Selected methods for soil and plant analysis. Manual Series No.1, IITA, Ibadan, Nigeria.

Jackson, R.B. et al. (2005) Trading water for carbon with biological carbon sequestration. Science, 310, 1944-1947.

Jaiyebo, E.O. \& Moore A.W. (1964) Soil fertility and nutrient storage in different soil-vegetation systems in a tropical rainforest environment. Trop. Agric. (Trinidad), 41, 129-139.

Jaiyeoba, I.A. (1995) Changes in soil properties related to different land uses in part of the Nigerian semi-arid Savannah. Soil Use Manag., 11, 84-89.

Jenkinson, D.S. \& Ayanaba A. (1977) Decomposition of carbon14 labeled plant material under tropical conditions. Soil Sci. Soc. Am. J., 41, 912-915.

Jolley, D. \& Pierre, W.H. (1977) Soil acidity from long-term use of nitrogen fertilizer and its relationship to recovery of nitrogen. Soil Sci. Soc. Am. J., 41, 368-373.

Junge, B. et al. (2010) First use of the ${ }^{137} \mathrm{Cs}$ technique in Nigeria for estimating medium-term redistribution rates on cultivated farmland. Soil Tillage Res., 110, 211-220.

Juo, A.S.R. \& Lal, R. (1977) The effects of fallow and continuous cultivation on the chemical and physical properties of Alfisol in western Nigeria. Plant Soil, 47, 567-564.

Juo, A.S.R. et al. (1995a) Acidification of a kaolinitic Alfisol under continuous cropping with $\mathrm{N}$ fertilization in West Africa. Plant Soil, 171, 245-253.

Juo, A.S.R. et al. (1995b) Changes in soil properties during longterm fallow and continuous cultivation after forest clearing in Nigeria. Agric. Ecosyst. Environ., 56, 9-18.

Juo, A.S.R. et al. (1996) Soil properties and crop performance on a kaolinitic Alfisol after 15 years of fallow and continuous cultivation. Plant Soil, 180, 209-217.

Kang, B.T. \& Spain, J.M. (1986) Management of low activity clays with special reference to Alfisols, Ultisols, and Oxisols in the tropics. In Proceedings of a symposium on low activity clay (LAC) soils. SMSS Tech. Monog. 14, Las Vegas, Nevada, 107-131.

Lal, R. (1987) Managing the soils of sub-Saharan Africa. Science, 236, 1069-1076.

Lamb, D. et al. (2005) Restoration of degraded tropical forest landscapes. Science, 310, 1628-1632.

Merckx, R. et al. (2001) Soil organic matter and soil fertility. In Sustaining soil fertility in West Africa. SSSA Spec. Publ. No. 58, eds. Tian, G., Ishida, F., Keatinge, D., SSSA, Madison, Wisconsin, 69-89.

Moormann, F.R. et al. (1975) The soils of IITA. IITA Tech. Bull. No. 3, IITA, Ibadan, Nigeria.

Muhr, L. et al. (2002) Soil mineral N dynamics and maize grain yields following Centrosema macrocarpum and Stylosanthes guianensis: Effects of different rotations and varying levels of N fertilizer. Field Crop. Res., 78, 197-209.

Pierre, W.H. et al. (1971) Quantitative effects of nitrogen fertilizer on the development and downward movement of soil acidity in relation to level of fertilization and crop removal in a continuous corn cropping system. Agron. J., 63, 291-297.

Sahrawat, K.L. et al. (2001) Application of inorganic phosphorus fertilizer. In Sustaining soil fertility in West Africa. SSSA Spec. Publ. No. 58, eds. Tian, G., Ishida, F., Keating, D., SSSA, Madison, Wisconsin, 225-246. 
Sanchez, P.A. et al. (1982) Amazon Basin soils: Management for continuous crop production. Science, 216, 821-827.

Sanchez, P.A. et al. (1983) Soil fertility dynamics after clearing a tropical forest in Peru. Soil Sci. Soc. Am. J., 47, 1171-1178.

Sanchez, P.A. et al. (1997) Soil fertility replenishment in Africa: An investment in natural resource capital. In Replenishing soil fertility in Africa. SSSA Spec. Publ. No. 51, eds. Buresh, R.J., Sanchez, P.A., Calhoun, F., SSSA, Madison, Wisconsin, $1-46$.

Sanchez, P.A. (2002) Soil fertility and hunger in Africa. Science, 295, 2019-2020.

Sharma, K.L. et al. (2009) Soil fertility and quality assessment under tree-, crop-, and pasture-based land-use systems in a rainfed environment. Commun. Soil Sci. Plant Anal., 40, 1436-1461.

Smaling, E.M.A. et al. (1997) Soil fertility in Africa is at stake. In Replenishing soil fertility in Africa. SSSA Spec. Publ. No. 51, eds. Buresh, R.J., Sanchez, P.A., Calhoun, F., SSSA, Madison, WI, 47-61.

Smyth, A.J. \& Montgomery, R.F. (1962) Soil and land use in
Central Western Nigeria. The Government of Western Nigeria, Ibadan, Nigeria.

Soil Survey Staff (1993) Soil survey manual, USDA Handbook No. 18, USDA, Washington DC.

Soil Survey Staff (2006) Keys to soil taxonomy, 10 ${ }^{\text {th }}$, edn. Nat. Resour. Conserv. Serv., USDA, Washington DC.

Stumpe, J.M. \& Vlek L.G. (1991) Acidification induced by different nitrogen sources in columns of selected tropical soils. Soil Sci. Soc. Am. J., 55, 145-151.

Thomas, M.L. et al. (1992) Land Use and Management Effects on Nonpoint Loading from Miamian Soil. Soil Sci. Soc. Am. J., 56, 1871-1875.

Van der Kruijs A.C.B.M. et al. (1988) Recovery of ${ }^{15} \mathrm{~N}$-labelled fertilizer in cops, drainage water and soil using monolith lysimeters in south-east Nigeria. Eur. J. Soil Sci., 39, 483-492.

Vanlauwe, B. et al. (2005) Senna siamea trees recycle Ca from a Ca-rich subsoil and increase the topsoil $\mathrm{pH}$ in agroforestry systems in the West African derived Savanna zone. Plant Soil, 269, 285-296. 